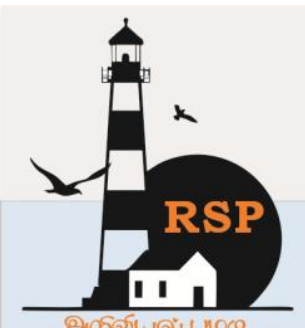

INTERNATIONAL RESEARCH JOURNAL ON

e-ISSN : 2582 - 4376 ADVANCED SCIENCE HUB Open Access

RSP SCIENCE HUB

(The Hub of Research Ideas)

Available online at www.rspsciencehub.com

\title{
Cultural Identity in Sustainable Architecture
}

Shanta Pragyan Dash ${ }^{1}$, Dr. Deepika Shetty ${ }^{2}$

${ }^{1}$ Assistant Professor-Senior Scale, Manipal School of Architecture \& Planning, Manipal.

${ }^{2}$ Professor. Manipal School of Architecture \& Planning, Manipal.

shanta.dash@manipal.edu ${ }^{1}$,deepika.shetty@manipal.edu ${ }^{2}$

\section{Abstract}

A highly debateabletopicin architectural fraternity is the 'sustainable architecture' which has been addressed in many publications. Literature terminology applies to different types of such architecture: 1970s eco-design, 1980s green design, late 1980s and 1990s ecological design. This demonstrates the emergence of a construction-oriented architecture that prioritizes the natural environment until the mid1990s. Sustainable architecture, on the other hand, as with all previous architecture approaches, can not only be considered a moral and architectural practice, but its contribution to social, cultural and economic infrastructure in the region. [1] UNESCO has coined "real life sustainability" to expand the overall concept of sustainable architecture from design to architecture incorporating local identity as part of the design process. [1] UNESCO coined the concept 'absolute sustainable life.'[2] Frampton aims to tackle local and contemporary global architectural culture at the same time as the notion of 'critical regionalism.' In his narrated essay, he stresses on value of sustainability in architecture as a cultural framework, not just a technique or process. [3] Culture defines a diverse concept that incorporates all intellectual activity of society. [4]Culture is; dynamic, exchanged, transformed into a new generation, expressed within the group and the person, interpreted in each community member. This includes laws, beliefs, principles, convictions and expectations. It transmits longevity and can improve the community's vitality. These are the assertion of "culture" in Matsumato's book "Psychology and Community."[5][6] The paper discusses about the sustainable cultural with architectural aspects. Part 1 discusses about eco-cultural architecture from various aspects of sustainable architecture. Next part 2 analyses worldclass construction practices as eco-cultural reasoning practices, and part 3 discusses a case study of Turkey's sustainable solutions to local issues.

Keywords: local identity, eco-cultural, sustainable architecture, culture.

\section{Introduction}

\subsection{The sustainable architecture eco-cultural design rationale}

The sustainable architecture eco-cultural design rationale

Guy and Farmer[7] defines sustainable architecture as an eco-technical, eco-centric, eco-aesthetic, ecocultural, eco-summary in Table 1, by six sections, and by the key rationale and methods. [8] The key environmental concern is one or more sustainable design logics. The principle of 'sustainable' can depend on logic to improve architecture. Sustainable architecture is defined as an energysufficient architecture that emphasizes technology development. Sustainable architecture is known as an infrastructure which is part of the nature utilizing natural resources and also has an ecological footprint of zero. Green architecture embraces environmental aesthetic philosophy with sensual, trendy and imaginative qualities. On its contrary, architecture creating a "healing environment" and encouraging people's healthy lifestyle is regarded as eco-medically sustainable. 
There is also an eco-social theory defining a sustainable architecture as collective spirit, freedom, and unity. The eco-cultural argument underlines that for society's stability, the majority of existing cultural archetypes is preserved and retained. This logic contributes to the conversion and use of traditional building methods, building typologies, and settlement patterns. This approach rejects standardized and technologically oriented design methodology, which sometimes does not suit a given place or person's cultural values. [9]

\section{Architectural projects with eco-cultural rationale}

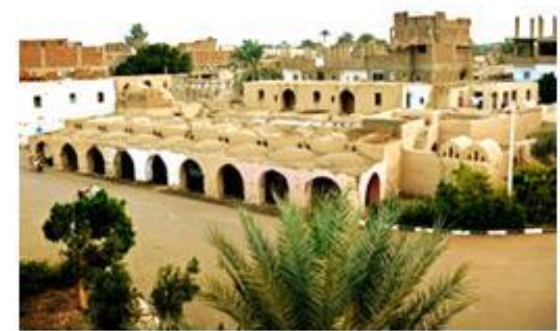

Figure 1: Gourna Village in Egypt dsignedby Hassan Fathy

The regional studies of Egypt's Hassan Fathy and Indian Charles Correa indicate a dedication to preserving cultural resources, to the continuity of spatial features, local materials and to the proper response of nature. New Gourna Village (Fig.1) translates from the common context of development and design the early perspective of Hassan Fathy's sustainable architecture. This ensures social security through the use of local resources, infrastructure and environment along with its exceptional resilience towards climate challenges. This is one of being anexcellent example of merging the heritage of vernacular with contemporary architecture.Fathy placed mud (adobe) bricks behind and kept building cooler during the day, using a variety of techniques and warmer during the nighttime. [11]. According to Fathy, new and older architectural methods should be mixed in architecture. Older techniques are sustainable and energized to contribute to reducing the reliance of villagers on modern technology, which both cost and impact their environment and culture. Notwithstanding the modern show of the "veranda" on a typical Indian bungalow in the Kanchenjunga apartments(Fig.2), the garden terraces have concrete constructions and large areas made of white panels.

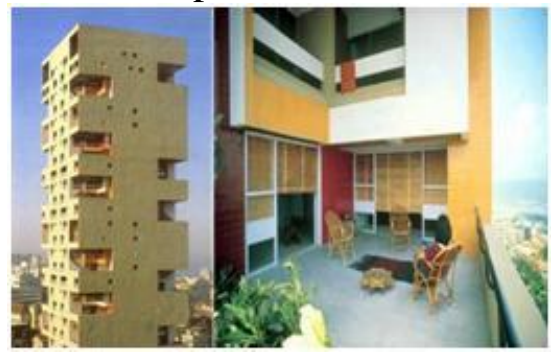

Figure 2: Kanchanjunga Apartments in India designed by Charles Correa

The garden veranda provides shading with protection for the high-rise units against sun and mountain rain. [12].

\section{Interpretation of Sustainable Architectural Practices:}

Residential buildings are the most famous examples of Turkish sustainable architecture (Fig.3).

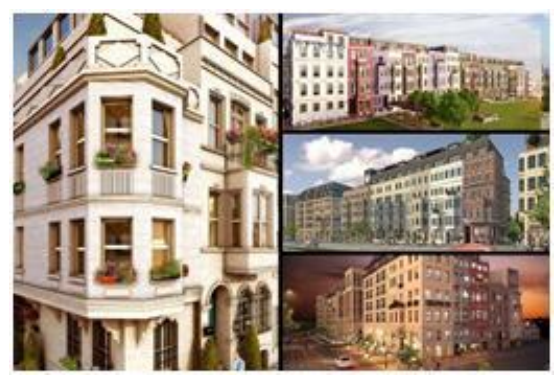

Figure 3: Turkish Architecture

There are a wide variety of households, including organic ones which reject modern building methods and harmonize nature with traditional and intelligent architecture, which saves energy consumption and is technologically rich. It is clear that sustainability and its main principles are not adequately explored and understood when studied in practice. Sustainable architecture in Turkey Sustainable constructions are referred to in some activities as high technology, self-production, lowenergy, passive, carbon neutral, sustainable building. In other words, Turkey's architecture deals not with social, political, environmental or economic realities but with the concept of morphology. Indoor and outdoor regions with green components show a systematic concept of sustainable growth, first digging virgin nature and then reaching it, avoiding locations while selecting materials such as the use of wood (natural) 


\section{www.rspsciencehub.com}

materials, and so on. [13] Architecture, childcare systems, settlement trends, land management mechanisms and land-ownership arrangements, dietary habits, symbolism. [14] Unlike contemporary architecture, the above-mentioned local cultural elements and suitable solutions to the local environment and geographic conditions are contained in Turkey's traditional architecture. Some traditional practices in Turkey are also usually considered sustainable.

\section{Discussions and Conclusion}

The new philosophy of sustainability contributes to debates on the principles of sustainable design. There have been advances in environmental design, including theory of eco-culture. It demonstrates the value of maintaining the architectural culture. This argues that the vital relationship between culture and environment is continually redefined. An ecological and cultural sustainability is accomplished through a regional architecture strategy. [15] Architecture is regional in landscape and topography. Architecture aims to reinforce regional culture by taking into account current regional systems, current building architectonic characteristics, existing resident lifestyles, and current cultural questions. In short, ecocultural meaning in sustainable architecture is met by regional design. In Turkish cases, it can be regarded as the absorption of modern architecture that is robust in understanding and utilizing traditional elements in a modern way. In this paper, finally, many sustainable design logics are examined. This provides a national study of sustainable building practices and outstanding architectural impact.

Table 1: Concurrent sustainable architectural rationale [8]

\begin{tabular}{|c|c|c|c|c|c|}
\hline Logic & Image of space & $\begin{array}{l}\text { Source of } \\
\text { environmental } \\
\text { knowledge }\end{array}$ & Building image & Technologies & Idealized concept of place \\
\hline Eco-technic & $\begin{array}{l}\text { global context } \\
\text { macrophysical }\end{array}$ & $\begin{array}{l}\text { technorational } \\
\text { scientific }\end{array}$ & $\begin{array}{l}\text { commercial } \\
\text { modern future- } \\
\text { oriented }\end{array}$ & $\begin{array}{l}\text { integrated } \\
\text { energy efficient } \\
\text { high-tech } \\
\text { intelligent }\end{array}$ & $\begin{array}{l}\text { Integration of global environmental } \\
\text { concerns into conventional building } \\
\text { design strategies - Urban vision of the } \\
\text { compact and dense city }\end{array}$ \\
\hline Eco-centric & $\begin{array}{l}\text { fragile } \\
\text { microbiotic }\end{array}$ & $\begin{array}{l}\text { systemic } \\
\text { ecology } \\
\text { metaphysical } \\
\text { holism }\end{array}$ & $\begin{array}{l}\text { polluter parasitic } \\
\text { consumer }\end{array}$ & $\begin{array}{l}\text { autonomous } \\
\text { renewable } \\
\text { recycled } \\
\text { intermediate }\end{array}$ & $\begin{array}{l}\text { Harmony with nature through } \\
\text { decentralized, autonomous buildings } \\
\text { with limited ecological footprints - } \\
\text { Ensuring the stability, integrity and } \\
\text { "flourishing of global and local diversity }\end{array}$ \\
\hline Eco-aesthetic & $\begin{array}{l}\text { alienating } \\
\text { antropocentric }\end{array}$ & $\begin{array}{l}\text { sensual } \\
\text { postmodern } \\
\text { science }\end{array}$ & $\begin{array}{l}\text { iconic } \\
\text { architectural } \\
\text { New Age }\end{array}$ & $\begin{array}{l}\text { pragmatic new } \\
\text { non-linear } \\
\text { organic }\end{array}$ & $\begin{array}{l}\text { Universally reconstructed in the light of } \\
\text { new ecologically knowledge and } \\
\text { transforming our-consciousness of } \\
\text { nature }\end{array}$ \\
\hline Eco-cultural & $\begin{array}{l}\text { Cultural context } \\
\text { regional }\end{array}$ & $\begin{array}{l}\text { phenomenology } \\
\text { cultural ecology }\end{array}$ & $\begin{array}{l}\text { authentic } \\
\text { harmonious } \\
\text { typological }\end{array}$ & $\begin{array}{l}\text { local low-tech } \\
\text { commonplace } \\
\text { vernacular }\end{array}$ & $\begin{array}{l}\text { Learning to "dwell" through buildings } \\
\text { adapted to local and bioregional physical } \\
\text { and cultural characteristics }\end{array}$ \\
\hline Eco-medical & $\begin{array}{l}\text { polluted } \\
\text { hazardous }\end{array}$ & $\begin{array}{l}\text { medical clinical } \\
\text { ecology }\end{array}$ & $\begin{array}{l}\text { healthy living } \\
\text { caring }\end{array}$ & $\begin{array}{l}\text { passive non- } \\
\text { toxic natural } \\
\text { tactile }\end{array}$ & $\begin{array}{l}\text { A natural and tactile environment which } \\
\text { ensures the health, well-being and } \\
\text { quality of life for individuals }\end{array}$ \\
\hline Eco-social & $\begin{array}{l}\text { social context } \\
\text { hierarchical }\end{array}$ & $\begin{array}{l}\text { sociology } \\
\text { social ecology }\end{array}$ & $\begin{array}{l}\text { democratic } \\
\text { home individual }\end{array}$ & $\begin{array}{l}\text { flexible } \\
\text { participatory } \\
\text { appropriate } \\
\text { locally managed }\end{array}$ & $\begin{array}{l}\text { Reconciliation of individual and } \\
\text { community in socially cohesive manner } \\
\text { through decentralized "organic". } \\
\text { nonhierarchical and participatory } \\
\text { communities }\end{array}$ \\
\hline
\end{tabular}




\section{References}

[1]. DurmuşArsan, Z. Türkiye'deSürdürülebilir Mimari. Mimarlık, Vol. 340, pp. 21-30, 2008.

[2]. Tocher, I. Review: Not quite Vegemite: An architectural resistance to the icon. http://www.vam.ac.uk/content/journals/rese arch-journal/issue-03/review-not-quitevegemite-anarchitectural-resistance-to-theicon/ (20.03.2012).

[3].McMinn, J. and Polo, M. Sustainable Architecture as A Cultural Project. Proceedings of theConference on World Sustainable Building, pp.4537-4544, Tokyo, Japan, 27-29 September 2005.

[4]. Ínceday,

D.

SürdürülebilirliğinKültürelBoyutu.

Sürdürülebilirlik: Kent veMimarlık, Bülten 51, pp. 30-35, 2007.

[5]. Ayalp, N. Cultural Identity and Place Identity in House Environment. 2nd International Conferenceon Arts and Culture, pp. 64-69, Montreux, Switzerland, 2011.

[6]. Matsumato D.R. and Juang, L. Culture and Psychology. Wadsworth Publishing, San Francisco,2003.

[7].Guy, S. and Farmer, G. Reinterpreting Sustainable Architecture: The Place of Technology. Journalof Architectural Education, Vol. 54, No. 3, pp. 140-148, 2001.

[8]. Ryan, A. Competing Logics of Sustainable Architecture in a New Zealand Competition.

http://www.cmsl.co.nz/assets/sm/5939/61/2 .PN062Ryan.pdf (18.03.2012).

[9]. Guy and Farmer, op.cit.

[10].UNESCO WHC. Safeguarding Project of Hassan Fathy's New Gourna Village. http://whc.unesco.org/en/activities/637/ (20.03.2012).

[11].Schoeman, A. Hassan Fathy: An Early Visionary of Sustainable Architecture. http://www.theinnovationdiaries.com/2613/ hassan-fathy-an-early-visionary-of sustainable architecture/(20.03.2012).

[12].Pagnotta, B. AD Classics: Kanchanjunga Apartments / Charles Correa. http://www.archdaily.com/151844/ad- classics-kanchanjunga-apartments-charlescorrea/(20.03.2012).

[13].DurmuşArsan, op.cit.

[14].Rapoport, A. House, Form and Culture. Prentice Hall, 1969.

[15].Sezer, M. Housing as a Sustainable Architecture in Turkey/ A Research on TOKI Housing. Masterof Science Thesis, METU, Ankara, 2009. 